\title{
PVRIG wt Allele
}

National Cancer Institute

\section{Source}

National Cancer Institute. PVRIG wt Allele. NCI Thesaurus. Code C156799.

Human PVRIG wild-type allele is located in the vicinity of $7 q 22.1$ and is approximately $5 \mathrm{~kb}$ in length. This allele, which encodes transmembrane protein PVRIG, may be involved in immune checkpoint signaling. 